\title{
MicroRNAs and Cardiovascular Disease
}

\author{
Carlos Fernández-Hernando · Ángel Baldán
}

Published online: 18 January 2013

(c) Springer Science + Business Media New York 2013

\begin{abstract}
MicroRNAs (miRNAs) regulate gene expression by binding to their targets and promoting RNA degradation and/or inhibiting protein translation. In recent years, miRNAs have revolutionized our understanding of gene regulatory networks, providing new prospective tools to manage disease. Atherosclerosis and other cardiovascular diseases are a leading cause of disability and death in the US and in other western populations and pose an enormous burden on our healthcare system. Altered lipid homeostasis in liver or in the artery wall, and disruption of endothelial and smooth muscle cell function have been shown to contribute to the onset and progression of cardiovascular disease. This review focuses on recent advances in the field of vascular biology- and lipid metabolism-related miRNomics.
\end{abstract}

Keywords miRNA - Lipid metabolism . Gene expression · Cardiovascular disease

C. Fernández-Hernando ( $\square)$

Departments of Medicine and Cell Biology, Leon H. Charney Division of Cardiology and the Marc and Ruti Bell Vascular Biology and Disease Program, New York University School of Medicine, 522 First Avenue, Smilow 703, New York, NY 10016, USA

e-mail: carlos.fernandez-hernando@nyumc.org

Á. Baldán

Edward A. Doisy Department of Biochemistry and Molecular Biology, Saint Louis University School of Medicine, Saint Louis, MO 63104, USA

Á. Baldán

Center for Cardiovascular Research, Saint Louis University,

Saint Louis, MO 63104, USA

\section{Introduction}

MicroRNAs (miRNAs) are non-coding, $\sim 22$ nucleotide RNAs that bind to specific, partially complementary sequences of target mRNAs, generally in the $3^{\prime}$-UTR [1-4]. This leads to RNA interference and/or translational repression of the target gene, thus resulting in reduced expression of the target mRNA [1]. miRNAs can be transcribed from their own promoter or can be encoded within the introns of other genes. It is thought that in the latter case these miRNAs are expressed when the "hosting" mRNA is transcribed [1-4]. Regardless, the original Pri-miRNA (up to several kb) is first processed by the exonuclease Drosha, and the resulting Pre-miRNA (100-150 nt) is then exported to the cytoplasm for further cleavage by Dicer to generate the mature miRNA (20-24 nt), which is finally incorporated into the RNA-induced silencing complex. Other, non-canonical pathways that are independent on Drosha or Dicer have been also described. Expression of particular miRNAs has been found in tissue, developmental and even disease-specific, revolutionizing our understanding of gene expression regulatory networks. Hence, recent studies have shown that miRNAs function as key mediators in multiple physiological and pathological-related biological processes. In this review we focus on the role of miRNAs in cardiovascular disease.

miRNAs, as Regulators of Endothelial Cell (EC) Function

Vascular ECs line the entire circulatory system and form the barrier between blood and all tissues. ECs are involved in many aspects of vascular biology ranging from inflammation, vasodilation and angiogenesis [5, 6]. Impaired EC function results in hypertension, thrombosis, inflammation and atherosclerosis [7]. Since 2006, several reports have 
demonstrated the critical role of miRNAs in regulating almost all ECs functions $[8 \cdot, 9 \bullet, 10 \bullet, 11]$. Here, we summarize the recent findings in the field highlighting the contribution of miR-126, miR-210, and the miR-17-92 miRNA cluster in controlling EC activation.

$\operatorname{miR}-126$

One of the first EC miRNA identified was miR-126, an EC-enriched miRNA that controls vascular inflammation by inhibiting the adhesion molecule VCAM-1 [12]. miR-126 also plays an important role in regulating angiogenic signaling and vascular integrity by directly repressing negative regulators of the vascular endothelial growth factor (VEGF) signaling pathway including the Sprouty-related protein (SPRED) 1 and the phosphoinositol-3 kinase regulatory subunit 2 (PIK3R2/p85 $\beta$ ) [13, 14]. In addition to the gene regulatory role of miR-126 in the cell where it is generated, several studies have shown that miR-126 is secreted in microparticles and apoptotic bodies and delivers paracrine signals to recipient vascular cell [15]. In this regard, Weber and colleagues showed that EC-derived apoptotic bodies were generated during atherosclerosis and demonstrated a paracrine signal to recipient vascular cells that triggered the production of CXCL12 [15]. Interestingly the administration of apoptotic bodies or miR-126 limited atherosclerosis by promoting the incorporation of Sca-1+ progenitor cells in the vessel wall. miR-126 has been also found in plasma vesicles and its expression is significantly reduced in plasma of patients with type-2 diabetes [16].

In addition to miR-126, other miRNAs including miR-181b, regulate EC activation by negatively modulating NF-K $\beta$ signaling pathway [17]. miR-181b expression is regulated by tumor necrosis factor (TNF) $\alpha$ and targets importing 3a (KPNA4), a protein required for NFK $\beta$ nuclear translocation. Similarly, TNF $\alpha$ also increases the expression of miR-17-3p and miR-31, which target ICAM1 and E-selectin, thereby reducing inflammation [18].

$\operatorname{miR}-210$

Hypoxia occurs during several physio-pathological circumstances including myocardial infarction, ischemia and tumor growth [19]. One of the early responses to hypoxia is the activation of ECs, which then migrate and proliferate in order to generate new vessels. Several reports recently demonstrated that the hypoxia-induced miR-210 regulates multiple aspects of the cellular response to low oxygen exposure including angiogenesis, migration, proliferation and metabolism. Thus, miR-210 regulates angiogenesis by controlling the expression of receptor tyrosine kinase Ephrin-A3 (EFNA3) [20, 21]. miR-210 overexpression also enhances endothelial cord formation, suggesting that
miR-210 alone is sufficient to promote angiogenesis [20]. Interestingly, the expression levels of miR-210 correlates with VEGF levels in breast cancer patients [22].

miR-17-92

$m i R-17-92$ is a polycistronic microRNA cluster that includes seven mature miRNAs $(m i R-17-5 p$ and $-3 p$, $m i R-18 a, m i R 19 a$ and $b, m i R-20 a$ and $m i R-92 a)$. This cluster was originally called oncomiR-1 for its strong association with a variety of tumors [23]. Several reports highlighted the contribution of several members of the cluster in regulating angiogenesis [11, 24-26]. Suárez and colleagues demonstrated that angiogenic chemokines such as VEGF induced the expression of some components of the miR-1792 cluster, leading to the repression of the thrombospondin1 , an anti-angiogenic molecule [11]. Other studies showed the important role of specific members of the cluster in regulating postnatal neovascularization [24-26]. In this regard, miR-92a regulates angiogenesis both in vitro and in vivo [25]. Thus, overexpression of miR-92a impairs angiogenesis in vitro and intersomic vessel growth in zebrafish [25]. Most importantly, anti-miR-92 therapy improves functional recovery after acute myocardial infarction [25]. Mechanistically, miR-92a directly regulates the expression of integrin subunit $\alpha 5$, a crucial regulator of EC growth. Moreover, miR-92a also regulates the endothelial nitric oxide synthase (eNOS), an enzyme that manufactures nitric oxide (NO) in ECs, thereby regulating vascular tone and angiogenesis. The molecular mechanism by which miR-92a regulates eNOS expression is complex. It has been recently shown that atheroprotective laminar flow reduces miR-92a levels, which inhibits KLF-2, a transcription factor that regulates eNOS expression [24]. KLF-2 also increases the expression of miR-143/145 in ECs [27]. Interestingly, both miRNAs are secreted in microvesicles and delivered to vascular smooth muscle cells (VSMCs) where they induce an atheroprotective effect by inhibiting the expression of the ETS oncogene family (ELK1), KLF4, calcium/calmodulin-dependent protein kinase II delta (CAMK2d), slingshot homolog 2 (SSH2), phosphatase, actin regulator 4 (PHACTR4) and cofilin 1 (CFL1) [27].

miRNAs VSMCs and Restenosis

VSMCs are the most abundant cells in the large arteries and play key roles in regulating vascular tone. These specialized cells secrete extracellular matrix components such as collagen and elastin, which determine the mechanical properties of the arteries. Alterations in VSMC function results in multiple cardiovascular diseases including hypertension, aortic aneurism, Marfan syndrome, supravalvular aortic stenosis and 
Williams-Beuren syndrome (WBS), which is characterized for mutations in the elastin gene [28-31]. Importantly, miRNAs play important roles in regulating VSMC functions and several studies have elegantly shown their potential for developing new drugs for ameliorating cardiovascular disorders including elastin haploinsufficient disorders [32].

The initial evidence that demonstrated the importance of miRNAs in controlling VSMC functions were provided using a mouse model with a conditional deletion of Dicer in VSMC [33, 34]. Absence of Dicer in VSMC results in embryonic lethality at E16.5 associated with extensive hemorrhage, defective organization of the elastic lamina and loss of contractile function in the umbilical artery [33]. In a following study, the same authors showed that miRNAs were also important in regulating VSMC homeostasis post-natally by deleting Dicer using a conditional inducible mouse model [34]. Importantly, the absence of Dicer leads to a dramatic reduction in blood pressure and to decreased contractile function in the bladder. Altogether, these studies suggest that the Dicer-dependent miRNAs are critical for the developmental and postnatal regulation of VSMCs function. In addition to the global role of miRNAs, specific miRNAs including miR-21, miR-143/145 and miR-29 were shown to play important roles in controlling VSMC functions [35-40, 41•, 42, 43•, 44, 45•, 46-48•, 49, 50•, 51].

miR-21

miR-21 regulates VSMCs proliferation and survival by inhibiting the expression of the phosphatase and tensin homolog (PTEN) and increasing Bcl-2 respectively [38]. Both effects were demonstrated in a carotid injury model. In addition to its role in cellular growth, miR-21 also promotes VSMCs differentiation in response to transforming growth factor and bone morphogenetic factor-4 [39]. Several reports have recently demonstrated the important role of miR-21 in regulating several cardiovascular disorders including the development of abdominal aortic aneurysm (AAA) and cardiac fibrosis [40]. miR-21 expression increases during AAA progression and its overexpression induces VSMCs proliferation and decreases apoptosis in the vascular wall [40]. Conversely, miR-21 inhibition diminished its pro-proliferative effect, leading to a significant increase in the size of AAA [40].

\section{miR-143/145}

The importance of the miR-143/145 miRNA cluster in controlling VSMCs functions was initially demonstrated in the miR-143/145 double mutant mice [41•, 42, 43•]. These animals are viable but they show a significant reduction in blood pressure and their response to vascular injury is significantly diminished [41•, 42, 43•]. Mechanistically,
miR-143/145 deficient-VSMCs show a marked inhibition of their migratory capacity accompanied by important alterations in the actin stress fibers. miR-143/145 also regulates VSMC plasticity and their absence results in a synthetic phenotype and lost of their contractile abilities [43•, 45•, 47]. These data demonstrate that miR-143/145 plays an important role in modulating VSMC phenotypic properties, which is critical during the progression of several vascular diseases such as atherosclerosis and AAA $[41 \cdot, 46]$.

$\operatorname{miR}-29$

miR-29 family members are encoded in two different loci that give rise a bicystronic precursors, which include $m i R-29 a / b l$ and $m i R-29 b 2 / c$. Several groups have published data recently highlighting the important role of miR-29 in controlling the expression of many components of the extracellular matrix such as elastin and collagen [48•, 49, 50•, 51, 52]. miR-29 is upregulated in aged arteries and in several murine models of aortic aneurysms [48•]. Very interestingly, therapeutic inhibition of miR-29 increases the expression of elastin and collagen and impairs the progression of aortic dilatation after angiotensin-II treatment [48•]. Similarly, miR-29 antisense oligonucleotides (ASO) increase the expression of elastin gene in cells isolated from WBS patients [50•]. These observations suggest that antagonism miR-29 in vivo might be a useful approach for treating elastin haploinsufficiencies and cardiovascular disease characterized by media destruction including AAA and atherosclerotic.

miRNAs, Lipid Metabolism and Atherosclerosis

Atherosclerosis is a progressive disorder of the vascular wall wherein massive amounts of cells and lipids accumulate in the sub-endothelial space [53]. Advanced plaques can eventually rupture leading to thrombotic events that are the primary cause of heart attack, stroke, and peripheral artery disease, which collectively account for $>30 \%$ of all deaths in the US. Multiple studies have recognized abnormal cholesterol homeostasis as a risk factor for the development of atherosclerosis. In the past few years, several laboratories have shed light on how miRNAs regulate lipid homeostasis (Fig. 1) and pointed to the potential of targeting specific miRNAs as potential new therapeutic weapons to manage atherosclerosis.

$m i R-33 a / b$

In 2010, five publications simultaneously reported that $m i R$ 33 (also known as $m i R-33 a$ or $m i R-33 a-5 p$ ) is expressed from within an intron of Srebp2, is induced by low intracellular 


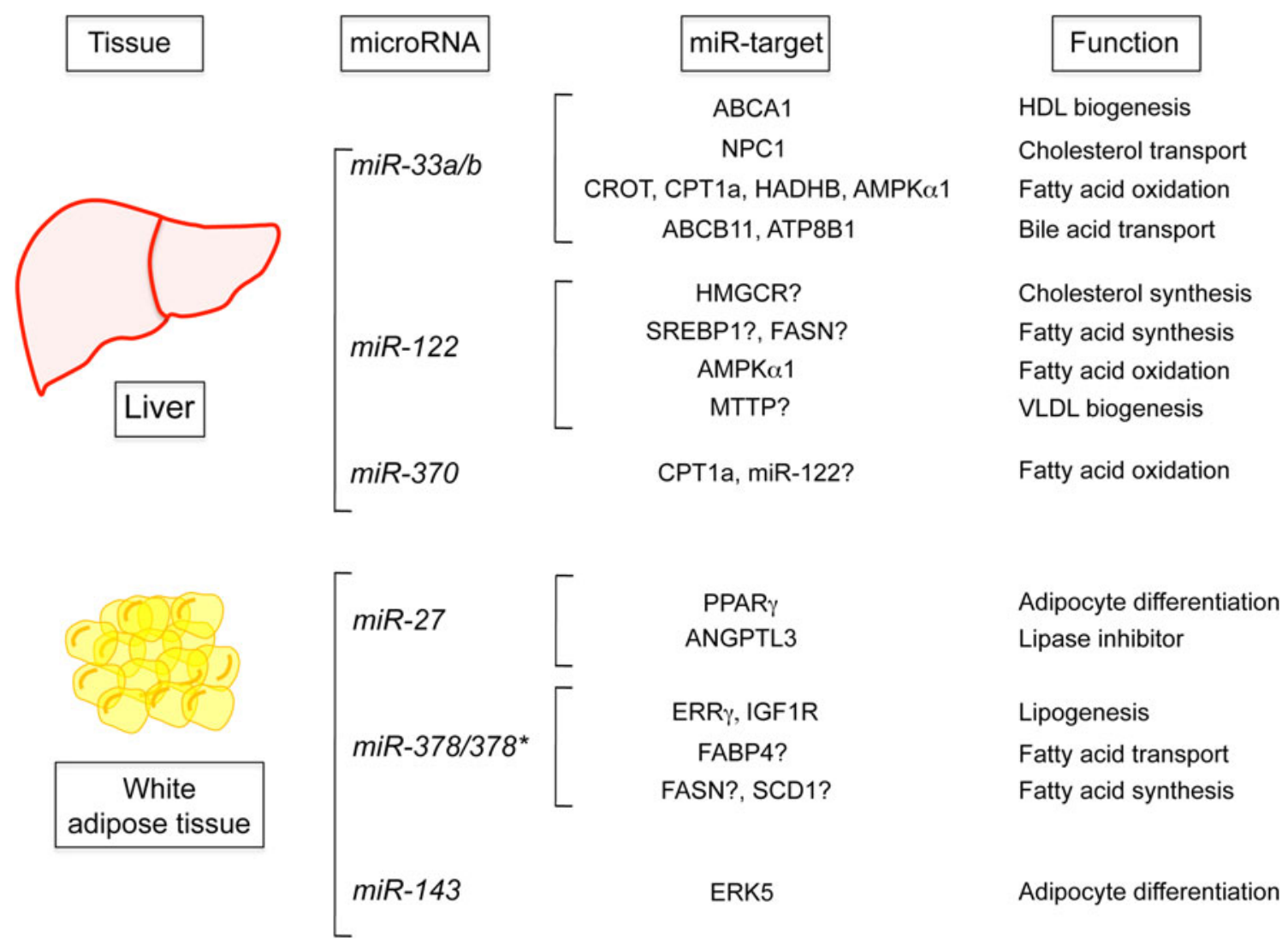

Fig. 1 miRNA regulation of lipid metabolism. Schematic overview of the most relevant miRNAs involved in regulating lipid metabolism in the liver and adipose tissue. Question mark indicates indirect target gene

cholesterol or following treatment with statins, and represses the expression of the sterol transporters ABCA1 and rodent,

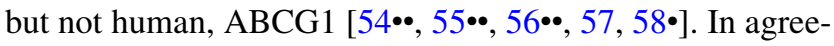
ment with these data, ASOs that silence miR-33 result in increased circulating high-density lipoprotein cholesterol $($ HDL-C) in mice $[54 \bullet \cdot, 55 \bullet, 56 \bullet]$. Primates, but not rodents, express a second $m i R-33$ gene $(m i R-33 b$ or $m i R-33 b-5 p)$ from an intron of Srebpl. Importantly, both Srebp genes are differentially regulated by dietary challenges or statin treatment. Hence, humanized mice in which transgenic $m i R-33 b$ is engineered to be expressed from an intron of Srebpl will be necessary to study the role of miR-33b on lipid metabolism. Initial studies also showed that miR-33 targeted genes involved in fatty acid $\beta$-oxidation, such as carnitine palmitoyltransferase 1A (Cptla), carnitine O-octanyl transferase (Crot), and hydroxyacyl-CoA dehydrogenase3-ketoacyl-CoA thiolase-enoyl-CoA hydratase (trifunctional protein) $\beta$-subunit (Hadhb) [57, 59॰]. Finally, a recent report showed that miR-33 also targets the hepatic bile transporters ABCB11 and ATP8B1 [60•]. Hence, silencing hepatic miR-33 expression resulted in a concomitant increase in both circulating HDL-C and bile secretion in mice.

Treatment of mice with anti-miR-33 oligonucleotides led to increased reverse cholesterol transport (RCT) in vivo
$[60 \bullet, 61]$. The RCT pathway mobilizes peripheral cholesterol into HDL back to the liver, where both cholesterol and its metabolite bile acids are secreted into bile for final excretion through the feces. In this context, the RCT is regarded as atheroprotective and strategies that promote/ accelerate the flow of cholesterol through this pathway are predicted to be effective in reducing the risk of cardiovascular disease in patients. Collectively, the initial reports on miR-33 suggested that patients with hypercholesterolemia might benefit from a therapy that incorporated silencing of miR-33 expression (e.g. miR-33 ASOs). In agreement with this notion, recent studies in non-human primates showed that treatment with miR-33 ASOs for 16 weeks increased circulating HDL-C, while at the same time reduced very-low density lipoprotein (VLDL)-triglycerides [62•]. These latter authors also reported that a 4-week antisense treatment of atherosclerosis-prone $L d l r$ mice with pre-existing atherosclerotic plaques resulted in accelerated regression of the atheromata [61]. Similarly, complete absence of miR-33 significantly reduces the progression of atherosclerosis in Apoe-deficient mice [63]. Based on these studies, miR-33 has emerged as a promising therapeutic target to manage cardiovascular disease. A more recent study, however, indicated that anti-miR-33 


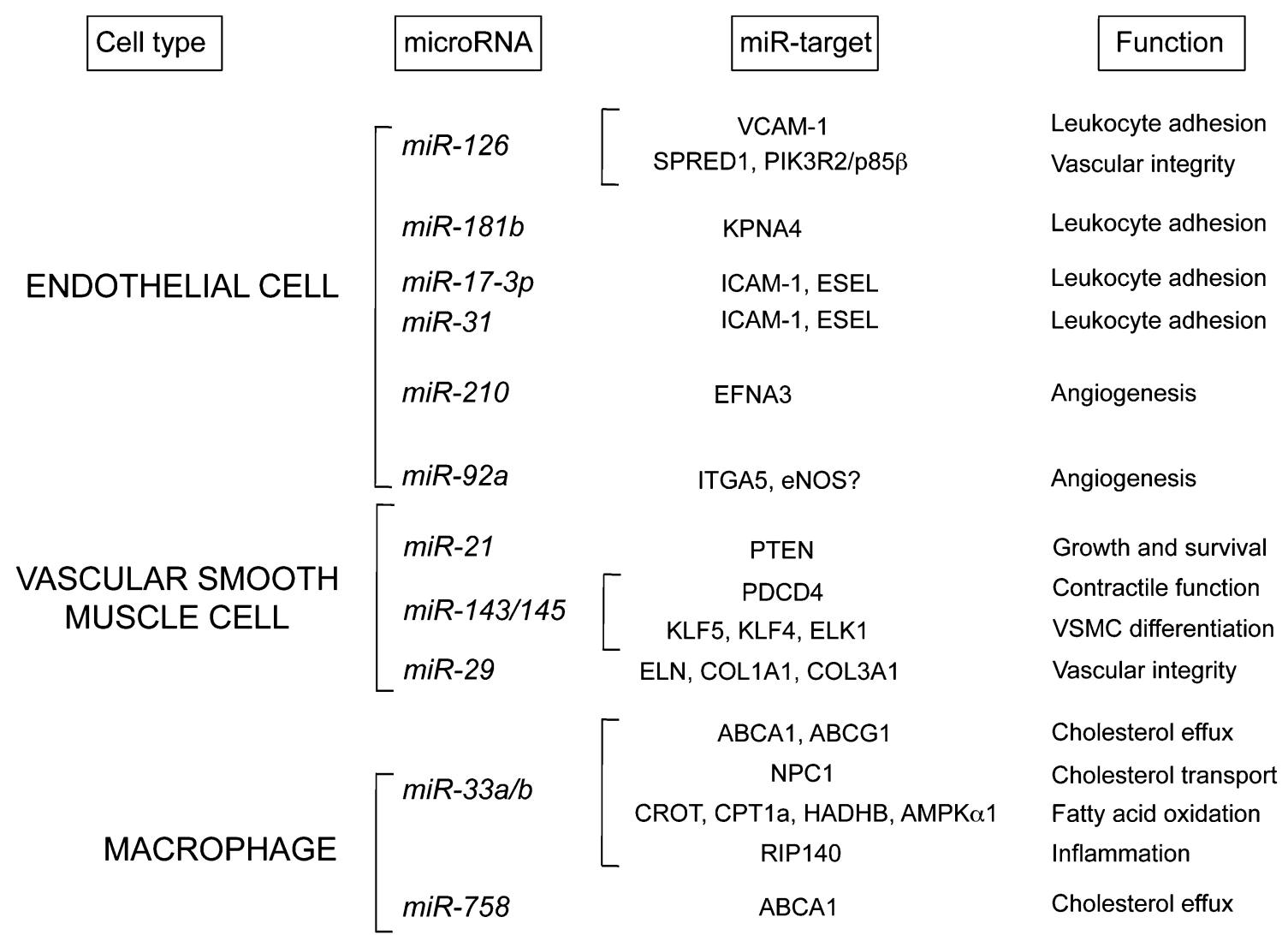

Fig. 2 Schematic overview of the most relevant cell types involved in vascular disease, as well as microRNAs that modulate their phenotype in disease progression. Question mark indicates indirect target gene

therapy does not alter the progression of atherosclerosis in LDLR-deficient mice [64].

miR-370 and $m i R-122$

The circulating levels of miR-370 and miR-122, but not $\mathrm{miR}-33 \mathrm{a} / \mathrm{b}$, were identified in a recent study to be increased in patients with hyperlipidemia and their expression correlated with coronary artery disease [65]. miR-370 and miR122 regulates lipid metabolism by controlling cholesterol and fatty acid synthesis and fatty acid $\beta$-oxidation [66-70]. Manipulation of miR-370 levels in human hepatic cells (HepG2) resulted in altered fatty acid $\beta$-oxidation and triglyceride synthesis, which correlated with changes in the expression levels of CPTI, SREBPIc, diacylglycerol O-acyltransferase 2 (DGAT2), fatty acid synthase (FAS) and acatyl-CoA carboxylase (ACC1) [70]. Importantly, these changes were abolished by miR-122 ASOs, suggesting that miR-122 expression is induced by miR-370 and that miR-122 is the effector miRNA. In agreement with these results, previous studies have showed that silencing miR-122 resulted in increased hepatic fatty acid $\beta$-oxidation and decreased triglyceride and cholesterol synthesis, and a concomitant decrease in circulating cholesterol [66]. Similar to the mice treated with miR-122 ASOs, circulating cholesterol and triglyceride levels were significantly reduced in mice lacking miR-122 compared with wild-type mice [68, 69]. These results were reproducible in non-human primates, making miR-122 another promising target to manage hypercholesterolemic patients [67]. It is important to stress, however, that the actual physiological targets of miR-122 remain to be established; it is believed that the changes in lipid metabolism mediated by miR-122 are indirect, since none of the above-mentioned genes are direct targets of this miRNA.

\section{Other miRNAs and Lipid Metabolism}

Recent studies have identified other miRNAs as integrators of complex lipid regulatory homeostatic pathways. For example, the expression of the human-specific miR-613 is induced by the oxysterol-sensing liver X receptor (LXR), via SREBP1c; hsa-miR-613 can subsequently bind to the $3^{\prime} \mathrm{UTR}$ and repress the expression of LXR, thus providing a negative feedback regulation of LXR-mediated signaling [71]. The intragenic $m i R-378 / 378 *$ is encoded within peroxisome proliferator-activated receptor gamma coactivator 1-beta (Ppargc1b) [72], and recent studies show that mice 
deficient in this miRNA have increased oxidative metabolic capacity and are protected against diet-induced obesity [73]. Functional targets for miR-378/378* include estrogen-related receptor gamma [74] and insulin-like growth factor 1 receptor [75], which may explain the increased lipogenesis observed following overexpression of miR-378/378* [72]. Other miRNAs including miR-27a/b, miR-143, miR-335, mi-106, miR-125a, and miR-758 have also been implicated in regulating triglyceride and cholesterol metabolism [76-82]. Whether any of these miRNAs will be developed as a drug targets to fight lipidrelated disease remains to be established.

\section{Conclusion}

Multiple studies have recently shown that miRNAs control critical aspects of lipid metabolism, lipoprotein homeostasis and vascular function (Fig. 2). A growing interest in anti-miR therapies is developing in recent years to treat cardiovascular disease. However, before such new therapeutic approaches are put in place, further studies will be necessary to define the specificity and potency of such antimiRs, vasculature-specific delivery routes, and the overall changes in gene expression that follow anti-miR treatment.

Acknowledgments Fernández-Hernando Lab and Baldán Lab are supported by grants from the National Institutes of Health (R01HL107953 and R01HL106063 to CF-H and R01HL107794 to $\mathrm{AB})$. We apologize to those whose work could not be cited owing to space limitations.

Disclosure The author reported no potential conflicts of interest relevant to this article.

\section{References}

Papers of particular interest, published recently, have been highlighted as:

- Of importance;

•- Of major importance

1. Bartel DP. MicroRNAs: target recognition and regulatory functions. Cell. 2009;136:215-33.

2. Ambros V. The functions of animal microRNAs. Nature. 2004;431:350-5.

3. Kloosterman WP, Plasterk RH. The diverse functions of microRNAs in animal development and disease. Dev Cell. 2006;11:441-50.

4. Huntzinger E, Izaurralde E. Gene silencing by microRNAs: contributions of translational repression and mRNA decay. Nat Rev Genet. 2011;12:99-110.

5. Carmeliet P. Angiogenesis in health and disease. Nat Med. 2003;9:653-60.

6. Pober JS, Sessa WC. Evolving functions o endothelial cells in inflammation. Nat Rev Immunol. 2007;7:803-15.
7. Otsuka F, Finn AV, Yazdani SK, Nakano M, Kolodgie FD, Virmani R. The importance of the endothelium in atherothrombosis and coronary stenting. Nat Rev Cardiol. 2012;8:439-53.

8. - Poliseno L, Tuccoli A, Mariani L, Evangelista M, Citti L, Woods K, Mercatanti A, Hammond S, Rainaldi G. MicroRNAs modulate the angiogenic properties of HUVECs. Blood. 2006;108:3068-71. This study was among the first to demonstrate the key role of miRNAs in regulating endothelial cell functions.

9. - Suárez Y, Fernández-Hernando C, Pober JS, Sessa WC. Dicer dependent microRNAs regulate gene expression and functions in human endothelial cells. Circ Res. 2007;100:1164-73. This study was among the first to demonstrate the key role of dicer-dependent miRNAs in regulating endothelial cell functions.

10. - Kuehbacher A, Urbich C, Zeiher AM, Dimmeler S. Role of Dicer and Drosha for endothelial microRNA expression and angiogenesis. Circ Res. 2007;101:59-68. This study was among the first to demonstrate the key role of miRNAs in regulating endothelial cell functions.

11. Suarez Y, Fernandez-Hernando C, Yu J, Gerber SA, Harrison KD, Pober JS, Iruela-Arispe ML, Merkenschlager M, Sessa WC. Dicer-dependent endothelial microRNAs are necessary for postnatal angiogenesis. Proc Natl Acad Sci USA. 2008;105:14082-7.

12. Harris TA, Yamakuchi M, Ferlito M, Mendell JT, Lowenstein CJ. MicroRNA-126 regulates endothelial expression of vascular cell adhesion molecule 1. Proc Natl Acad Sci USA. 2008;105:1516-21.

13. Fish JE, Santoro MM, Morton SU, Yu S, Yeh RF, Wythe JD, Ivey KN, Bruneau BG, Stainier DY, Srivastava D. miR-126 regulates angiogenic signaling and vascular integrity. Dev Cell. 2008;2:272-84.

14. Wang S, Aurora AB, Johnson BA, Qi X, McAnally J, Hill JA, Richardson JA, Bassel-Duby R, Olson EN. The endothelial-specific microRNA miR-126 governs vascular integrity and angiogenesis. Dev Cell. 2008;2:261-71.

15. Zernecke A, Bidzhekov K, Noels H, Shagdarsuren E, Gan L, Denecke B, Hristov M, Koppel T, Jahantigh MN, Lutgens E, Wang S, Olson EN, Schober A, Weber C. Delivery of microRNA-126 by apoptotic bodies induces CXCL12-dependent vascular protection. Sci Signal. 2009;. doi:10.1126/scisignal. 2000610.

16. Zampetaki A, Kiechl S, Drozdov I, Willeit P, Mayr U, Prokopi M, Mayr A, Weger S, Oberhollenzer F, Bonora E, Shah A, Willeit J, Mayr M. Plasma microRNA profiling reveals loss of endothelial miR-126 and other microRNAs in type 2 diabetes. Circ Res. 2010;6:810-7.

17. Sun X, Icli B, Wara AK, Belkin N, He S, Kobzik L, Hunninghake GM, Vera MP, Blackwell TS, Baron RM, Feinberg MW. MicroRNA-181b regulates NF-kappaB-mediated vascular inflammation. J Clin Invest. 2012;122:1973-90.

18. Suarez Y, Wang C, Manes TD, Pober JS. Cutting edge: TNFinduced microRNAs regulate TNF-induced expression of E-selectin and intercellular adhesion molecule-1 on human endothelial cells: feedback control of inflammation. J Immunol. 2010;184:21-5.

19. Fraisl P, Mazzone M, Schmidt T, Carmeliet P. Regulation of angiogenesis by oxygen and metabolism. Dev Cell. 2009;2:167-79.

20. Fasanaro P, D'Alessandra Y, Di Stefano V, Melchionna R, Romani S, Pompilio G, Capogrossi MC, Martelli F. MicroRNA210 modulates endothelial cell response to hypoxia and inhibits the receptor tyrosine kinase ligand Ephrin-A3. J Biol Chem. 2008;283:15878-83.

21. Chan SY, Loscalzo J. MicroRNA-210: a unique and pleiotropic hypoxamir. Cell Cycle. 2010;16:1072-83.

22. Camps C, Buffa FM, Colella S, Moore J, Sotiriou C, Sheldon H, Harris AL, Gleadle JM, Ragoussis J. hsa-miR-210 Is induced by hypoxia and is an independent prognostic factor in breast cancer. Clin Cancer Res. 2008;14:1340-8. 
23. Hayashita $\mathrm{Y}$, Osada $\mathrm{H}$, Tatematsu $\mathrm{Y}$, et al. A polycistronic microRNA cluster, miR-17-92, is overexpressed in human lung cancers and enhances cell proliferation. Cancer Res. 2005;65: 9628-32.

24. Wu W, Xiao H, Laguna-Fernandez A, Villarreal G Jr, Wang KC, Geary GG, Zhang Y, Wang WC, Huang HD, Zhou J, Li YS, Chien S, Garcia-Cardena G, Shyy JY. Flow-dependent regulation of kruppel-like factor 2 is mediated by microRNA-92a. Circulation. 2011;124:633-41.

25. Bonauer A, Carmona G, Iwasaki M, Mione M, Koyanagi M, Fischer A, Burchfield J, Fox H, Doebele C, Ohtani K, Chavakis E, Potente M, Tjwa M, Urbich C, Zeiher AM, Dimmeler S. MicroRNA-92a controls angiogenesis and functional recovery of ischemic tissues in mice. Science. 2009;324:1710-3.

26. Doebele C, Bonauer A, Fischer A, Scholz A, Reiss Y, Urbich C, Hofmann WK, Zeiher AM, Dimmeler S. Members of the microRNA-17-92 cluster exhibit a cell-intrinsic antiangiogenic function in endothelial cells. Blood. 2010;23:4944-50.

27. Hergenreider E, Heydt S, Treguer K, Boettger T, Horrevoets AJ, Zeiher AM, Scheffer MP, Frangakis AS, Yin X, Mayr M, Braun T, Urbich C, Boon RA, Dimmeler S. Atheroprotective communication between endothelial cells and smooth muscle cells through miRNAs. Nat Cell Biol. 2012;14:249-56.

28. Marx SO, Totary-Jain H, Marks AR. Vascular smooth muscle cell proliferation in restenosis. Circ Cardiovasc Interv. 2011;4:104-11.

29. Alexander MR, Owens GK. Epigenetic control of smooth muscle cell differentiation and phenotypic switching in vascular development and disease. Annu Rev Physiol. 2012;74:13-40.

30. Lacolley P, Regnault V, Nicoletti A, Li Z, Michel JB. The vascular smooth muscle cell in arterial pathology: a cell that can take on multiple roles. Cardiovasc Res. 2012;2:194-204.

31. Gorenne I, Kavurma M, Scott S, Bennett M. Vascular smooth muscle cell senescence in atherosclerosis. Cardiovasc Res. 2006; 72:9-17.

32. Kang H, Hata A. MicroRNA regulation of smooth muscle gene expression and phenotype. Curr Opin Hematol. 2012;19:224-31.

33. Albinsson S, Suarez Y, Skoura A, Offermann s S, Miano JM, Sessa WC. MicroRNAs are necessary for vascular smooth muscle growth, differentiation, and function. Arterioscler Thromb Vasc Biol. 2010;30:1118-26.

34. Albinsson S, Skoura A, Yu J, DiLorenzo A, Fernandez-Hernando C, Offermanns S, Miano JM, Sessa WC. Smooth muscle miRNAs are critical for post-natal regulation of blood pressure and vascular function. PLoS One. 2011;6:e18869.

35. Sarkar J, Gou D, Turaka P, Viktorova E, Ramchandran R, Raj JU. MicroRNA-21 plays a role in hypoxia-mediated pulmonary artery smooth muscle cell proliferation and migration. Am J Physiol Lung Cell Mol Physiol. 2010;299:L861-71.

36. Wang M, Li W, Chang GQ, Ye CS, Ou JS, Li XX, Liu Y, Cheang TY, Huang XL, Wang SM. MicroRNA-21 regulates vascular smooth muscle cell function via targeting tropomyosin 1 in arteriosclerosis obliterans of lower extremities. Arterioscler Thromb Vasc Biol. 2011;31:2044-53.

37. Song JT, Hu B, Qu HY, Bi CL, Huang XZ, Zhang M. Mechanical stretch modulates microRNA 21 expression, participating in proliferation and apoptosis in cultured human aortic smooth muscle cells. PLoS One. 2012;7:e47657.

38. Ji R, Cheng Y, Yue J, Yang J, Liu X, Chen H, Dean DB, Zhang C. MicroRNA expression signature and antisense-mediated depletion reveal an essential role of MicroRNA in vascular neointimal lesion formation. Circ Res. 2007;100:1579-88.

39. Kang H, Davis-Dusenbery BN, Nguyen PH, Lal A, Lieberman J, Van Aelst L, Lagna G, Hata A. Bone morphogenetic protein 4 promotes vascular smooth muscle contractility by activating microRNA-21 (miR-21), which down-regulates expression of family of dedicator of cytokinesis (DOCK) proteins. J Biol Chem. 2012;287:3976-86.

40. Maegdefessel L, Azuma J, Toh R, Deng A, Merk DR, Raiesdana A, Leeper NJ, Raaz U, Schoelmerich AM, McConnell MV, Dalman RL, Spin JM, Tsao PS. MicroRNA-21 blocks abdominal aortic aneurysm development and nicotine-augmented expansion. Sci Transl Med. 2012;122:122ra22.

41. • Boettger T, Beetz N, Kostin S, Schneider J, Kruger M, Hein L, Braun T. Acquisition of the contractile phenotype by murine arterial smooth muscle cells depends on the Mir143/145 gene cluster. J Clin Invest 2009;119:2634-47. This study uncovers a role for miR-143/145 microRNA cluster in regulating smooth muscle cell plasticity.

42. Elia L, Quintavalle M, Zhang J, Contu R, Cossu L, Latronico MV, Peterson KL, Indolfi C, Catalucci D, Chen J, Courtneidge SA, Condorelli G. The knockout of miR-143 and -145 alters smooth muscle cell maintenance and vascular homeostasis in mice: correlates with human disease. Cell Death Differ. 2009;16:1590-8.

43. - Xin M, Small EM, Sutherland LB, Qi X, McAnally J, Plato CF, Richardson JA, Bassel-Duby R, Olson EN. MicroRNAs miR-143 and miR-145 modulate cytoskeletal dynamics and responsiveness of smooth muscle cells to injury. Genes Dev. 2009;23:2166-78. This study uncovers a role for miR-143/145 microRNA cluster in regulating smooth muscle cell plasticity and cytoskeletal morphology.

44. Cheng Y, Liu X, Yang J, Lin Y, Xu DZ, Lu Q, Deitch EA, Huo Y, Delphin ES, Zhang C. MicroRNA-145, a novel smooth muscle cell phenotypic marker and modulator, controls vascular neointimal lesion formation. Circ Res. 2009;105:158-66.

45. - Cordes KR, Sheehy NT, White MP, Berry EC, Morton SU, Muth AN, Lee TH, Miano JM, Ivey KN, Srivastava D. miR-145 and miR-143 regulate smooth muscle cell fate and plasticity. Nature. 2009;460:705-10. This study uncovers a role for miR143/145 microRNA cluster in regulating smooth muscle cell plasticity and cytoskeletal morphology.

46. Lovren F, Pan Y, Quan A, Singh KK, Shukla PC, Gupta N, Steer BM, Ingram AJ, Gupta M, Al-Omran M, Teoh H, Marsden PA, Verma S. MicroRNA-145 targeted therapy reduces atherosclerosis. Circulation. 2012;126:S81-90.

47. Davis-Dusenbery BN, Chan MC, Reno KE, Weisman AS, Layne MD, Lagna G, Hata A. Down-regulation of Kruppel-like factor-4 (KLF4) by microRNA-143/145 is critical for modulation of vascular smooth muscle cell phenotype by transforming growth factor-beta and bone morphogenetic protein 4. J Biol Chem. 2011;286:28097-110.

48. - Boon RA, Seeger T, Heydt S, Fischer A, Hergenreider E, Horrevoets AJ, Vinciguerra M, Rosenthal N, Sciacca S, Pilato M, van Heijningen P, Essers J, Brandes RP, Zeiher AM, Dimmeler S. MicroRNA-29 in aortic dilation: implications for aneurysm formation. Circ Res. 2011;109:1115-9. This study uncovers a role for miR-29 in regulating the expression of extracellular matrix components, thereby regulating vascular integrity.

49. van Rooij E, Sutherland LB, Thatcher JE, DiMaio JM, Naseem RH, Marshall WS, Hill JA, Olson EN. Dysregulation of microRNAs after myocardial infarction reveals a role of miR-29 in cardiac fibrosis. Proc Natl Acad Sci USA. 2008;105:13027-32.

50. - Zhang P, Huang A, Ferruzzi J, Mecham RP, Starcher BC, Tellides G, Humphrey JD, Giordano FJ, Niklason LE, Sessa WC. Inhibition of microRNA-29 enhances elastin levels in cells haploinsufficient for elastin and in bioengineered vessels-brief report. Arterioscler Thromb Vasc Biol. 2012;32:756-9. This study demonstrate that anti-miR-29 therapy might be useful for treating elastin haploinsufficiencies including the WilliamsBeuren syndrome. 
51. Merk DR, Chin JT, Dake BA, Maegdefessel L, Miller MO, Kimura N, Tsao PS, Iosef C, Berry GJ, Mohr FW, Spin JM, Alvira CM, Robbins RC, Fischbein MP. miR-29b participates in early aneurysm development in Marfan syndrome. Circ Res. 2012;110:312-24.

52. Suarez Y, Fernandez-Hernando C. New insights into microRNA29 regulation: a new key player in cardiovascular disease. J Mol Cell Cardiol. 2012;52:584-6.

53. Glass CK, Witztum JL. Atherosclerosis: the road ahead. Cell. 2001;104:503-16.

54. •• Rayner KJ, Suarez Y, Davalos A, Parathath S, Fitzgerald ML, Tamehiro N, Fisher EA, Moore KJ, Fernandez-Hernando C. MiR33 contributes to the regulation of cholesterol homeostasis. Science. 2010;328:1570-3. This study was among the first to demonstrate the key role of miR-33 in regulating cellular cholesterol efflux and circulating HDL cholesterol.

55. • Najafi-Shoushtari SH, Kristo F, Li Y, Shioda T, Cohen DE, Gerszten RE, Naar AM. MicroRNA-33 and the SREBP host genes cooperate to control cholesterol homeostasis. Science. 2010;328:1566-9. This study was among the first to demonstrate the key role of $\mathrm{miR}-33$ in regulating cellular cholesterol efflux and circulating HDL cholesterol.

56. • Marquart TJ, Allen RM, Ory DS, Baldan A. miR-33 links SREBP-2 induction to repression of sterol transporters. Proc Natl Acad Sci USA 2010;107:12228-32. This study was among the first to demonstrate the key role of miR-33 in regulating cellular cholesterol efflux and circulating HDL cholesterol.

57. Gerin I, Clerbaux LA, Haumont O, Lanthier N, Das AK, Burant CF, Leclercq IA, Macdougald OA, Bommer GT. Expression of miR-33 from an SREBP2 intron inhibits cholesterol export and fatty acid oxidation. J Biol Chem. 2010;285:33652-61.

58. - Horie T, Ono K, Horiguchi M, Nishi H, Nakamura T, Nagao K, Kinoshita M, Kuwabara Y, Marusawa H, Iwanaga Y, Hasegawa K, Yokode M, Kimura T, Kita T. MicroRNA-33 encoded by an intron of sterol regulatory element-binding protein 2 (Srebp2) regulates HDL in vivo. Proc Natl Acad Sci USA 2010;107:17321-6. This study demonstrate genetically the importance of miR-33 in regulating plasma HDL cholesterol levels.

59. - Davalos A, Goedeke L, Smibert P, Ramirez CM, Warrier NP, Andreo U, Cirera-Salinas D, Rayner K, Suresh U, Pastor-Pareja JC, Esplugues E, Fisher EA, Penalva LO, Moore KJ, Suarez Y, Lai EC, Fernandez-Hernando C. miR-33a/b contribute to the regulation of fatty acid metabolism and insulin signaling. Proc Natl Acad Sci USA 2011;108:9232-7. This study uncovers a role for miR-33 in regulating fatty acid oxidation and insulin signalling and suggest that anti-miR-33 therapy would be usefull for treating metabolic syndrome.

60. - Allen RM, Marquart TJ, Albert CJ, Suchy FJ, Wang DQ, Ananthanarayanan M, Ford DA, Baldán A. miR-33 controls the expression of biliary transporters, and mediates statin- and dietinduced hepatotoxicity. EMBO Mol Med. 2012;4:882-95. This study uncovers a role for miR-33 in controlling the expression of bile transporters, thereby increasing the reverse cholesterol transport.

61. Rayner KJ, Sheedy FJ, Esau CC, Hussain FN, Temel RE, Parathath S, van Gils JM, Rayner AJ, Chang AN, Suarez Y, Fernandez-Hernando C, Fisher EA, Moore KJ. Antagonism of miR-33 in mice promotes reverse cholesterol transport and regression of atherosclerosis. J Clin Invest. 2011;121:2921-31.

62. - Rayner KJ, Esau CC, Hussain FN, McDaniel AL, Marshall SM, van Gils JM, Ray TD, Sheedy FJ, Goedeke L, Liu X, Khatsenko OG, Kaimal V, Lees CJ, Fernandez-Hernando C, Fisher EA, Temel RE, Moore KJ. Inhibition of miR-33a/b in non-human primates raises plasma HDL and lowers VLDL triglycerides. Nature. 2011;478:404-7. This study demonstrates the efficacy of
anti-miR-33 therapy in raising circulating HDL cholesterol and lowering VLDL triglycerides in non-human primates.

63. Horie T, Baba O, Kuwabara Y, Chujo T, Watanabe S, Kinoshita M, Horiguchi M, Nakamura T, Chonabayashi K, Hishizawa M, Hasegawa K, Kume N, Yokode M, Kita T, Kimura T, Ono K. MicroRNA-33 deficiency reduces the progression of atherosclerotic plaque in apoE-/- mice. J Am Heart Assoc. 2012;1: e003376.

64. Gao W, He HW, Wang ZM, Zhao H, Lian XQ, Wang YS, Zhu J, Yan JJ, Zhang DG, Yang ZJ, Wang LS. Plasma levels of lipometabolism-related miR-122 and miR-370 are increased in patients with hyperlipidemia and associated with coronary artery disease. Lipids Health Dis. 2012;. doi:10.1186/1476-511X-11-55.

65. Marquart TJ, Wu J, Lusis AJ, Baldán A. Anti-miR-33 therapy does not alter the progression of atherosclerosis in low-density lipoprotein receptor-deficient mice. Arterioscler Thromb Vasc Biol. 2013;. doi:10.1161/ATVBAHA.112.300639.

66. Esau C, Davis S, Murray SF, Yu XX, Pandey SK, Pear M, Watts L, Booten SL, Graham M, McKay R, Subramaniam A, Propp S, Lollo BA, Freier S, Bennett CF, Bhanot S, Monia BP. miR-122 regulation of lipid metabolism revealed by in vivo antisense targeting. Cell Metab. 2006;3:87-98.

67. Krützfeldt J, Rajewsky N, Braich R, Rajeev KG, Tuschl T, Manoharan M, Stoffel M. Silencing of microRNAs in vivo with 'antagomirs'. Nature. 2005;438:685-9.

68. Tsai WC, Hsu SD, Hsu CS, Lai TC, Chen SJ, Shen R, Huang Y, Chen HC, Lee CH, Tsai TF, Hsu MT, Wu JC, Huang HD, Shiao MS, Hsiao M, Tsou AP. MicroRNA-122 plays a critical role in liver homeostasis and hepatocarcinogenesis. J Clin Invest. 2012; 122:2884-97.

69. Hsu SH, Wang B, Kota J, Yu J, Costinean S, Kutay H, Yu L, Bai S, La Perle K, Chivukula RR, Mao H, Wei M, Clark KR, Mendell JR, Caligiuri MA, Jacob ST, Mendell JT, Ghoshal K. Essential metabolic, anti-inflammatory, and anti-tumorigenic functions of miR-122 in liver. J Clin Invest. 2012;122:2871-83.

70. Iliopoulos D, Drosatos K, Hiyama Y, Goldberg IJ, Zannis VI. MicroRNA-370 controls the expression of microRNA-122 and Cpt1alpha and affects lipid metabolism. J Lipid Res. 2010;51: 1513-23.

71. Ou Z, Wada T, Gramignoli R, Li S, Strom SC, Huang M, Xie W. MicroRNA hsa-miR-613 targets the human LXR $\alpha$ gene and mediates a feedback loop of LXR $\alpha$ autoregulation. Mol Endocrinol. 2011;25:584-96.

72. Gerin I, Bommer GT, McCoin CS, Sousa KM, Krishnan V, MacDougald OA. Roles for miRNA-378/378* in adipocyte gene expression and lipogenesis. Am J Physiol Endocrinol Metab. 2010;2992:E198-206.

73. Carrer M, Liu N, Grueter CE, Williams AH, Frisard MI, Hulver MW, Bassel-Duby R, Olson EN. Control of mitochondrial metabolism and systemic energy homeostasis by microRNAs 378 and 378*. Proc Natl Acad Sci USA. 2012;109:15330-5.

74. Eichner LJ, Perry MC, Dufour CR, Bertos N, Park M, St-Pierre J, Giguère V. miR-378(*) mediates metabolic shift in breast cancer cells via the PGC-1 $\beta / E R R ~ \gamma$ transcriptional pathway. Cell Metab. 2010;12:352-61.

75. Knezevic I, Patel A, Sundaresan NR, Gupta MP, Solaro RJ, Nagalingam RS, Gupta M. A novel cardiomyocyte-enriched microRNA, miR-378, targets insulin-like growth factor 1 receptor: implications in postnatal cardiac remodeling and cell survival. J Biol Chem. 2012;287:12913-26.

76. Vickers KC, Shoucri BM, Levin MG, Wu H, Pearson DS, OseiHwedieh D, Collins FS, Remaley AT, Sethupathy P. MicroRNA$27 \mathrm{~b}$ is a regulatory hub in lipid metabolism and is altered in dyslipidemia. Hepatology. 2012; doi:10.1002/hep. 25846.

77. Fernández-Hernando $\mathrm{C}$. The emerging role of miRNAs in the regulation of lipid metabolism. Hepatology. 2012;. doi:10.1002/hep.25960. 
78. Lin Q, Gao Z, Alarcon RM, et al. A role of miR-27 in the regulation of adipogenesis. FEBS J. 2009;276:2348-58.

79. Nakanishi N, Nakagawa Y, Tokushige N, et al. The up-regulation of microRNA-335 is associated with lipid metabolism in liver and white adipose tissue of genetically obese mice. Biochem Biophys Res Commun. 2009;385:492-6.

80. Esau C, Kang X, Peralta E, et al. MicroRNA-143 regulates adipocyte differentiation. J Biol Chem. 2004;279:52361-5.

81. Kim J, Yoon H, Ramírez CM, Lee SM, Hoe HS, FernándezHernando C, Kim J. MiR-106b impairs cholesterol efflux and increases $\mathrm{A} \beta$ levels by repressing ABCA1 expression. Exp Neurol. 2012;235:476-83.

82. Ramirez CM, Dávalos A, Goedeke L, Salerno AG, Warrier N, Cirera-Salinas D, Suárez Y, Fernández-Hernando C. MicroRNA758 regulates cholesterol efflux through posttranscriptional repression of ATP-binding cassette transporter A1. Arterioscler Thromb Vasc Biol. 2011;31:2707-14. 